Check for updates

Cite this: Dalton Trans., 2020, 49 10901

Received 22nd June 2020

Accepted 16 th July 2020

DOI: $10.1039 / \mathrm{d} 0 \mathrm{dt} 02209 \mathrm{~h}$

rsc.li/dalton

\title{
Dinuclear Tb and Dy complexes supported by hybrid Schiff-base/calixarene ligands: synthesis, structures and magnetic properties $\uparrow$
}

\author{
Peter Hahn, ${ }^{a}$ Steve Ullmann, ${ }^{a}$ Jennifer Klose, ${ }^{a}$ Yan Peng, ${ }^{b}$ Annie K. Powell $\mathbb{D}^{\mathrm{b}}{ }^{\mathrm{b}}$ and \\ Berthold Kersting (D) *a
}

\begin{abstract}
The synthesis of the new lanthanide complexes $\left[\mathrm{HNEt}_{3}\right]\left[\mathrm{Dy}_{2}\left(\mathrm{HL}^{1}\right)\left(\mathrm{L}^{1}\right)\right](\mathbf{5})$, and $\left[\mathrm{Ln}_{2}\left(\mathrm{~L}^{2}\right)_{2}\right]\left(\mathrm{Ln}^{2}=\mathrm{Tb}^{\mathrm{III}}(\mathbf{7})\right.$, Dy (8)) supported by the hybrid Schiff-base/calix[4]arene ligands $\mathrm{H}_{4} \mathrm{~L}^{1}$ (25-[2-((2-methylphenol)imino) ethoxy]-26,27,28-trihydroxy-calix[4]arene) and $\mathrm{H}_{3} \mathrm{~L}^{2}$ (25-[2-((2-methylpyridine)imino)ethoxy]-26,27,28trihydroxy-calix[4]arene) are reported. Spectroscopic data (for 5 ) and X-ray crystallographic analysis (for 7.4MeCN, 8.4MeCN) reveal the presence of dimeric structures, featuring doubly-bridged $\mathrm{NO}_{4} \mathrm{Ln}$ $(\mu-O)_{2} L_{n} O_{4} N(5)$ or $\mathrm{N}_{2} \mathrm{O}_{3} \mathrm{Ln}(\mu-\mathrm{O})_{2} \mathrm{LnO}_{3} \mathrm{~N}_{2}$ cores $(\mathbf{7}, \mathbf{8})$ with seven-coordinated $\mathrm{Ln}^{3+}$ ions. The magnetic properties of polycrystalline samples of $\mathbf{5 , 7}$ and $\mathbf{8}$ were studied by variable temperature dc and ac magnetic susceptibility measurements. The $\chi^{\prime \prime}(T)$ vs. $T$ plots show no maxima in zero field, but the maxima can be detected under a $3 \mathrm{kOe}$ dc field. The relaxation times $\tau$ obey the Arrhenius law above $5 \mathrm{~K}$. Anisotropy barriers of $\sim 18 \mathrm{~cm}^{-1}(26 \mathrm{~K})$ for 5 and $\sim 23 \mathrm{~cm}^{-1}$ (33 K) for 8 were determined.
\end{abstract}

\section{Introduction}

The synthesis and investigation of magnetic properties of novel types of lanthanide complexes are very important for the development of molecular based magnetic materials, ${ }^{1-3}$ and many different types of lanthanide complexes with remarkable magnetic properties have been reported in the last several years. ${ }^{4-7}$ In 2003, slow relaxation of the magnetization was observed in the mononuclear lanthanide complexes $\left[\mathrm{Pc}_{2} \mathrm{~Tb}\right]^{-}$ and $\left[\mathrm{Pc}_{2} \mathrm{Dy}\right]^{-}$, where $\mathrm{Pc}=$ phthalocyaninato, and this discovery spurred the search for other lanthanide-based single-molecule magnets (SMMs) ${ }^{8}$ Considerable efforts have been dedicated to the understanding of the mechanisms in mono- and polynuclear 4f SMMs in order to inform and direct ongoing research. It has been established that variation of the ligand field symmetry and coordination geometry, alteration of the charge and type of the donor atoms, and the type and magnitude of exchange interactions (in polynuclear systems) can have a great effect on the single ion anisotropy of the coordinated $\mathrm{Ln}^{3+}$ ions and thus the dynamics of the magnetiza-

\footnotetext{
${ }^{a}$ Institut für Anorganische Chemie, Universität Leipzig, Johannisallee 29, D-04103 Leipzig, Germany. E-mail: b.kersting@uni-leipzig.de; Fax: +49/(0)341-97-36199 ${ }^{b}$ Institute of Inorganic Chemistry, Karlsruhe Institute of Technology, Engesserstrasse 15, D-76131 Karlsruhe, Germany.E-mail: annie.powell@kit.edu

$\dagger$ Electronic supplementary information (ESI) available. CCDC 2011007 and 2011008. For ESI and crystallographic data in CIF or other electronic format see DOI: $10.1039 / \mathrm{d} 0 \mathrm{dt} 02209 \mathrm{~h}$
}

tion. ${ }^{9}$ Polydentate ligands have turned out to be ideal candidates for systematic investigations because they can be rationally designed to control the coordination environment of the lanthanide ions. ${ }^{10}$ Thus, phthalocyaninato, ${ }^{11} \beta$-diketonato, ${ }^{12}$ calix[4]arenes, ${ }^{13}$ and various Schiff base ligands ${ }^{14,15}$ or mixtures thereof ${ }^{16}$ have been used extensively in synthesizing functional coordination compounds of the $4 \mathrm{f}$ elements. In addition, these complexes have the added advantage that they can be developed for surface deposition, and in turn for device applications. ${ }^{17,18}$

Several dinuclear terbium ${ }^{19-24}$ and dysprosium complexes with SMM behaviour have been reported. ${ }^{16,25-32}$ Most are mixed-ligand complexes, with the coordination spheres often being partly completed by solvate molecules or the anions. We previously reported a hybrid Schiff-base/calixarene ligand $\mathrm{H}_{4} \mathrm{~L}^{1}$ (Fig. 1) that supports homoleptic lanthanide complexes $\left[\mathrm{HNEt}_{3}\right]\left[\operatorname{Ln}_{2}\left(\mathrm{HL}^{1}\right)\left(\mathrm{L}^{1}\right)\right]$ without additional coligands. ${ }^{33}$ Hybrid ligands of this sort are known to complex first-row transition metals readily, but their lanthanide chemistry, particularly their magnetic properties, ${ }^{13,34}$ remains largely unexplored. ${ }^{35-42}$ In order to investigate the effect of donor atom variations on the structures and properties of such lanthanide calix[4]arene complexes, we have now focused on the coordination properties of the ligand $\mathrm{H}_{3} \mathrm{~L}^{2}$, bearing a pyridyl-aldiminato podand arm in place of a salicylaldimine unit.

Herein, we report the synthesis, structures and magnetic properties of the corresponding $\mathrm{Tb}^{\mathrm{III}}$ and $\mathrm{Dy}^{\mathrm{III}}$ complexes 7 and 8 (Fig. 1). Their properties are compared with those of 

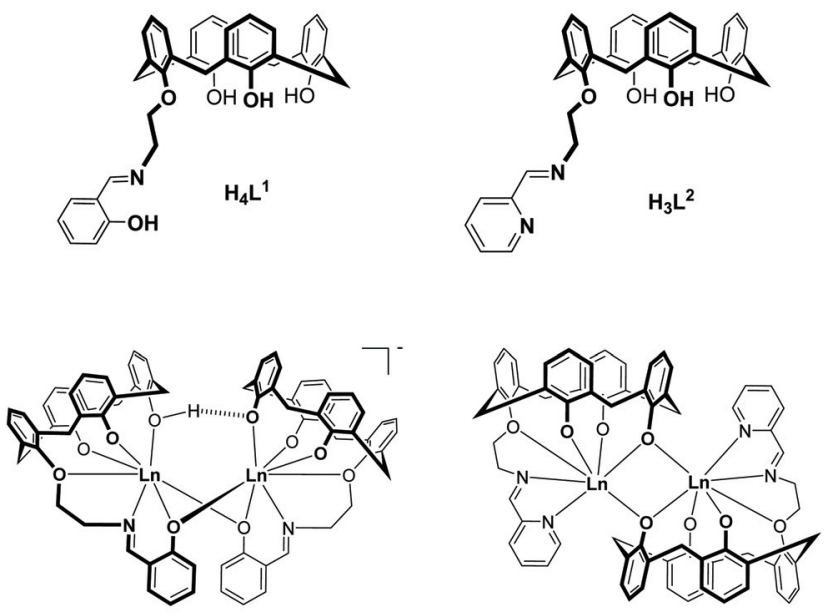

$\left(\mathrm{HNEt}_{3}\right)\left[\mathrm{Ln}_{2}\left(\mathrm{HL} \mathrm{L}^{1}\right)\left(\mathrm{L}^{1}\right)\right.$ $(\operatorname{Ln}=\operatorname{Sm}(1), \mathrm{Eu}(2), \mathrm{Gd}(3), \mathrm{Tb}(4), \mathrm{Dy}(5))$

$$
\begin{gathered}
{\left[\operatorname{Ln}_{2}\left(\mathrm{~L}^{2}\right)_{2}\right]} \\
\operatorname{Ln}=\operatorname{Tb}(7), \operatorname{Dy}(8)
\end{gathered}
$$

Fig. 1 Structures of hybrid Schiff-base/calix[4]arene ligands $\mathrm{H}_{4} \mathrm{~L}^{1}$ and $\mathrm{H}_{3} \mathrm{~L}^{2}$ and their lanthanide complexes 1-5, 7, and 8. The complexes 1-4 have been reported previously. ${ }^{33}$

complexes 4 and 5. The contrasting responses to dynamic magnetic fields (in an applied DC field) are discussed in terms of the different coordination environments and geometries.

\section{Results and discussion}

\section{Synthesis and spectroscopic characterization}

The new ligand $\mathrm{H}_{3} \mathrm{~L}^{2}$ was obtained in $74 \%$ yield by a Schiffbase condensation between 25-(aminoethoxy)-26,27,28-trihydroxy-calix[4]arene 6 and pyridine-2-carbaldehyde as illustrated in eqn (1). ${ }^{43} \mathrm{H}_{3} \mathrm{~L}^{2}$ is soluble in aprotic solvents such as $\mathrm{CH}_{2} \mathrm{Cl}_{2}, \mathrm{CHCl}_{3}, \mathrm{DMSO}, \mathrm{MeCN}$ and insoluble in alcohols. $\mathrm{H}_{3} \mathrm{~L}^{2}$ was characterized by IR, ${ }^{1} \mathrm{H}$ and ${ }^{13} \mathrm{C}$ NMR spectroscopy and electrospray ionization mass spectrometry (ESI-MS). The NMR spectra show one set of signals. 2D NMR experiments were performed to correctly assign the chemical shifts of hydrogen and carbon atoms (ESI $\dagger$ ). The data are in accordance with the formulation of $\mathrm{H}_{3} \mathrm{~L}^{2}$ and the "cone"-conformation of the calix[4] arene unit in $\mathrm{H}_{3} \mathrm{~L}^{2}$.

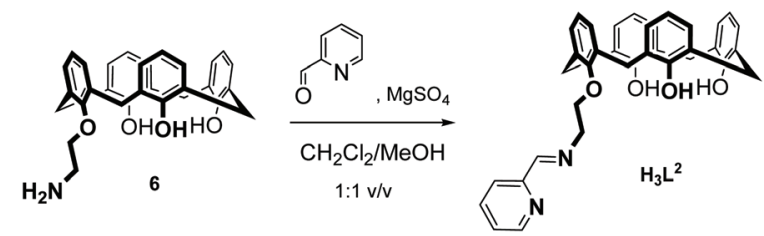

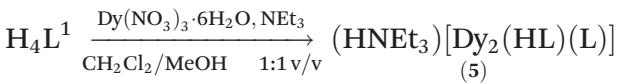

$$
\begin{aligned}
& \mathrm{H}_{3} \mathrm{~L}^{2} \underset{\mathrm{CH}_{2} \mathrm{Cl}_{2} / \mathrm{MeOH} \quad 1: 1 \mathrm{v} / \mathrm{v}}{\stackrel{\mathrm{Ln}\left(\mathrm{NO}_{3}\right)_{3} \cdot 6 \mathrm{H}_{2} \mathrm{O}, \mathrm{NEt}_{3}}{\longrightarrow}} \underset{(\operatorname{Ln}=\mathrm{Tb}(7), \operatorname{Dy}(8))}{\left[\operatorname{Ln}_{2}\left(\mathrm{~L}^{2}\right)_{2}\right]}
\end{aligned}
$$

The syntheses of the $\mathrm{Sm}^{\mathrm{III}}{ }_{2}, \mathrm{Gd}^{\mathrm{III}}{ }_{2}, \mathrm{Eu}^{\mathrm{III}}{ }_{2}$ and $\mathrm{Tb}^{\mathrm{III}}{ }_{2}$ complexes 1-4 have been reported previously. ${ }^{33}$ The corresponding
Dy ${ }^{\text {III }}$ complex 5 was synthesized in an analogous fashion (eqn (2)). Similarly, reaction of $\mathrm{H}_{3} \mathrm{~L}^{2}$ with terbium(III) nitrate hexahydrate or dysprosium(III) nitrate hexahydrate and $\mathrm{NEt}_{3}$ as a base in a mixed $\mathrm{CH}_{2} \mathrm{Cl}_{2} / \mathrm{MeOH}$ solution at room temperature, followed by extraction from MeCN affords $\left[\operatorname{Ln}_{2}\left(\mathrm{~L}^{2}\right)_{2}\right] \cdot 4 \mathrm{MeCN}$ complexes (7.4MeCN, 8.4MeCN) as yellow crystals in $85-87 \%$ yield (eqn (3)). The compounds are air stable, have little solubility in common organic solvents, and lose solvate molecules upon standing in air. All new complexes were characterized by elemental analysis, mass spectrometry, and IR spectroscopy, and additionally by X-ray crystallography (for $7 \cdot 4 \mathrm{MeCN}$, 8.4MeCN). Table 1 lists selected analytical data.

A negative ESI-MS spectrum of a solution of $5\left(10^{-3} \mathrm{M}\right)$ in MeCN displays a molecular ion peak at $m / z=1461.25$ with the correct isotopic peak pattern for a dimeric $\left[\mathrm{Dy}_{2}\left(\mathrm{HL}^{1}\right)\left(\mathrm{L}^{1}\right)\right]^{-}$ anion (ESI). A signal at $m / z=730.12$ for a monomeric $\left[\mathrm{Dy}\left(\mathrm{L}^{1}\right)\right]^{-}$ species is also observed. Similar peaks were observed for complexes 1-4. ${ }^{33}$ Complexes 7 and 8 were investigated by ESI MS in MeCN (concentration $\sim 10^{-3} \mathrm{M}$ ) using the positive mode. Under these conditions, molecular ion peaks with the correct isotopic peak pattern for dimeric $\left[\mathrm{Ln}_{2}\left(\mathrm{~L}^{2}\right)_{2}+\mathrm{H}^{+}\right]^{+},\left[\mathrm{Ln}_{2}\left(\mathrm{~L}^{2}\right)_{2}+\right.$ $\left.\mathrm{Na}^{+}\right]^{+}$or $\left[\operatorname{Ln}_{2}\left(\mathrm{~L}^{2}\right)_{2}+\mathrm{K}^{+}\right]^{+}$cations are detected (Fig. S7-S10†). Signals for monomeric $\left[\mathrm{Ln}\left(\mathrm{L}^{2}\right)+\mathrm{H}^{+}\right]^{+}$species are also observed, but all attempts to isolate monomeric complexes failed so far. The dimerisation is believed to be driven by the coordination requirements of the lanthanide ions. As in $\mathrm{H}_{3} \mathrm{~L}^{1}$, the hexadentate $\mathrm{N}_{2} \mathrm{O}_{4}$ ligand $\mathrm{H}_{3} \mathrm{~L}^{2}$ cannot saturate the coordination sphere of the lanthanide ions alone and so dimerization via bridging phenolate atoms takes place to increase the coordination number. Peaks characteristic for host guest complexes with intracavity MeCN molecules could not be detected.

The FTIR spectrum of $\mathbf{5}$ is similar to those of 1-4, with a strong band at $1635 \mathrm{~cm}^{-1}$ for the $\nu(\mathrm{C}=\mathrm{N})$ stretching frequency. A broad band at $3439 \mathrm{~cm}^{-1}$ is attributed to the $\mathrm{O}-\mathrm{H}$ stretching vibration. The $\nu(\mathrm{C}-\mathrm{O})$ stretching frequency observed for $\mathrm{H}_{4} \mathrm{~L}^{1}$ at $1338 \mathrm{~cm}^{-1}$ is shifted to $1327 \mathrm{~cm}^{-1}$, indicative of the coordination of the pendant phenol ether moiety. ${ }^{44}$

The most characteristic bands in the FTIR-spectrum of $\mathrm{H}_{3} \mathrm{~L}^{2}$ are the bands at $1651 \mathrm{~cm}^{-1}$ for the imine group $(\nu(\mathrm{C}=\mathrm{N}))$ and a broad feature at $3250 \mathrm{~cm}^{-1}$ for the $\mathrm{O}-\mathrm{H}$ stretches of the calix[4]arene moiety. The latter band is not seen in the IR spectra of the $\left[\operatorname{Ln}_{2}\left(\mathrm{~L}^{2}\right)_{2}\right]$ complexes in agreement with the triply deprotonated form of $\mathrm{H}_{3} \mathrm{~L}^{2}$. The stretching vibration for the imine group is observed at $1651 \mathrm{~cm}^{-1}$ for $\mathrm{H}_{3} \mathrm{~L}^{2}, 1652 \mathrm{~cm}^{-1}$ for 7 and $1655 \mathrm{~cm}^{-1}$ for 8 , respectively. The intensity of the $\nu(\mathrm{C}=\mathrm{N})$ band decreases significantly upon coordination of the lanthanide ions.

\section{X-ray crystallography}

We have not been able to grow single-crystals of the $\mathrm{Dy}_{2}{ }_{2}$ complex 5. However, on the basis of the spectroscopic data, this complex is believed to be isostructural with the $\mathrm{Sm}_{2}^{\mathrm{III}}$ (1) and $\mathrm{Gd}_{2}^{\mathrm{III}}$ complexes (3), both of which have been crystallographically characterized. ${ }^{33}$

Single crystals of $\left[\mathrm{Tb}_{2}\left(\mathrm{~L}^{2}\right)_{2}\right] \cdot 4 \mathrm{MeCN}(7 \cdot 4 \mathrm{MeCN})$ obtained by extraction from $\mathrm{MeCN}$ were found to be suitable for X-ray crys- 
Table 1 Selected analytical data for the supporting ligands $\mathrm{H}_{4} \mathrm{~L}^{1}, \mathrm{H}_{3} \mathrm{~L}^{2}$ and their lanthanide complexes 5,7 and 8

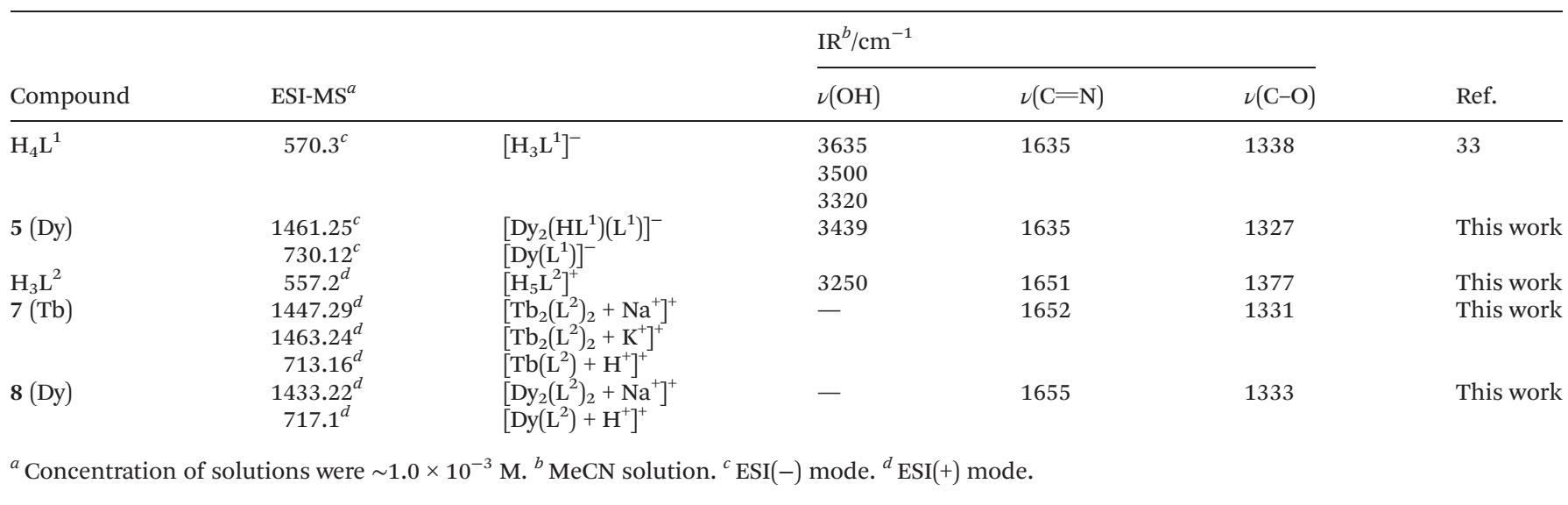

tallographic analyses. The crystal structure determination revealed the presence of dimeric $\left[\mathrm{Tb}_{2}\left(\mathrm{~L}^{2}\right)_{2}\right] \cdot 4 \mathrm{MeCN}$ complexes (Fig. 2). There are two heavily disordered MeCN solvent molecules, which were removed from the structure using the Squeeze routine implemented in Platon. ${ }^{45}$ Two well-defined MeCN molecules are situated in the calix[4] arene cavities as in other calix[4]arene structures. ${ }^{46}$

Complex 7 exhibits crystallographically imposed $C_{2}$ symmetry, with the $C_{2}$ axis passing through the centre of a central four-membered $\mathrm{Tb}_{2} \mathrm{O}_{2}$ ring. Two $\left[\mathrm{Tb}^{\mathrm{III}}\left(\mathrm{L}^{2}\right)\right]$ units are joined by

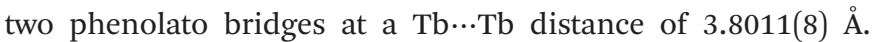
This structure is strikingly different from that seen in 1-5. In the latter, dimerization occurs via phenolato groups from the pendant salicylaldimine units, while $\left[\mathrm{Tb}^{\mathrm{III}}\left(\mathrm{L}^{2}\right)\right]$ monomers are

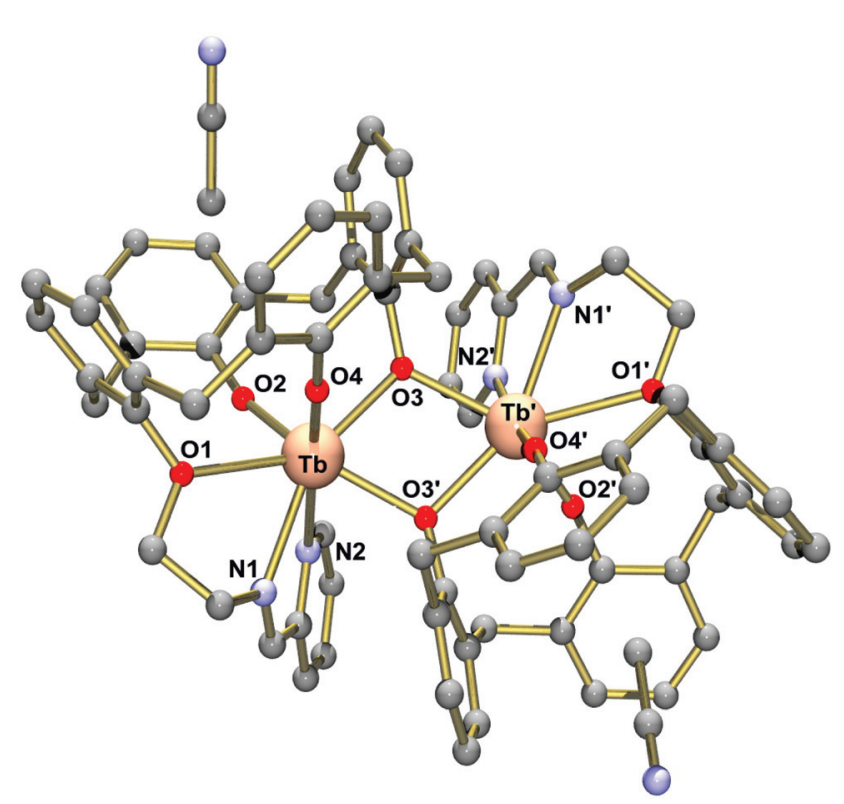

Fig. 2 Molecular structure of the neutral $\left[\mathrm{Tb}_{2}\left(\mathrm{~L}^{2}\right)_{2}\right]$ complex in crystals of $7.4 \mathrm{MeCN}$ (Ball and stick representation). The disordered $\mathrm{MeCN}$ solvate molecules are omitted for clarity. Symmetry code used to generate equivalent atoms $0.5-x,-0.5+y,-z$. linked via phenolato groups from the capping calix[4]arene entities. In 1-5, one $\mathrm{Ln}^{3+}$ ion adopts a capped octahedral geometry and the other is a capped trigonal prism as indicated by the SHAPE algorithm (ESI). ${ }^{47}$ Conversely, in 7 , both $\mathrm{Ln}^{3+}$ ions are surrounded in a distorted capped trigonal prismatic fashion by five calix[4] arene $\mathrm{O}$, one imine $\mathrm{N}$ and one pyridyl $\mathrm{N}$ atom. Also the $\mathrm{Ln}_{2} \mathrm{O}_{2}$ cores in the $C_{i}$ symmetric complexes 1-5 are bent, while the $\mathrm{Tb}_{2} \mathrm{O}_{2}$ core in 7 is almost flat, with the $\mathrm{TbO}_{2}$ planes intersecting at $12.5^{\circ}$. It should be noted that the dimerization mode of the calix[4] arene units in 7 is reminiscent of that seen in lanthanide complexes supported by unmodified calixarene ligands. The complexes [ $\{\mathrm{Eu}(4$-tert-butyl-calix (4)arene) $\left.\left.(\mathrm{DMF})_{2}\right\}\right]^{48}$ and $\left[\{\mathrm{Nd}(\operatorname{calix}[4] \mathrm{H})(\text { thf })\}_{2}\right]^{49}$ represent two typical examples. There are other dimeric $\mathrm{Ln}_{2}$ complexes containing phenolato bridges, but the coordination numbers tend to be higher than in the present case. ${ }^{50-52}$ Significant interactions between the complexes are not observed due to the steric bulk of the supporting ligand. Thus, the closest intermolecular $\mathrm{Tb} \cdots \mathrm{Tb}$ distance is at $9.145 \AA$ A.

Table 2 lists selected bond lengths and angles. The Tb-O bond lengths vary considerably from 2.136(5) A to 2.605(5) Å. The $\mathrm{Tb}-\mathrm{O}$ bonds involving the non-bridging phenolato groups $(\mathrm{O} 2, \mathrm{O} 4)$ are significantly shorter than those involving the bridging phenolato groups (O3, O3') (mean value $2.33 \AA$ ), as in other seven-coordinate $\mathrm{Tb}^{\mathrm{III}}$ calix[4]arene complexes. ${ }^{13,53}$ The

Table 2 Selected bond lengths $/ \AA$ and angles $/{ }^{\circ}$ for $7.4 \mathrm{MeCN}$ and 8.4MeCN

\begin{tabular}{lcc}
\hline & {$\left[\mathrm{Tb}_{2}\left(\mathrm{~L}^{2}\right)_{2}\right] \cdot 4 \mathrm{MeCN}$} & {$\left[\mathrm{Dy}_{2}\left(\mathrm{~L}^{2}\right)_{2}\right] \cdot 4 \mathrm{MeCN}$} \\
\hline $\mathrm{M}-\mathrm{O} 1$ & $2.605(5)$ & $2.608(6)$ \\
$\mathrm{M}-\mathrm{O} 2$ & $2.136(5)$ & $2.134(5)$ \\
$\mathrm{M}-\mathrm{O} 3$ & $2.323(5)$ & $2.311(5)$ \\
$\mathrm{M}-\mathrm{O} 3^{\prime}$ & $2.345(4)$ & $2.343(5)$ \\
$\mathrm{M}-\mathrm{O} 4$ & $2.109(5)$ & $2.106(6)$ \\
M-N1 & $2.536(7)$ & $2.509(7)$ \\
M-N2 & $2.691(7)$ & $2.675(8)$ \\
M-M-M' & $3.8011(8)$ & $3.7819(9)$ \\
& & \\
$\mathrm{M}-\mathrm{O} 3-\mathrm{M}$ & $109.03(18)$ &
\end{tabular}




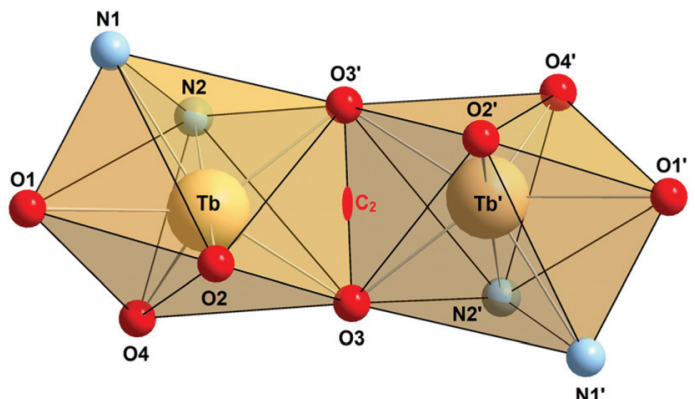

Fig. 3 Polyhedral representation of the dinuclear $\mathrm{N}_{2} \mathrm{O}_{3} \mathrm{~Tb}(\mu-\mathrm{O})_{2} \mathrm{TbO}_{3} \mathrm{~N}_{2}$ core in $7.4 \mathrm{MeCN}$ highlighting the mono-capped trigonal prismatic coordination geometry. The $C_{2}$ axis is indicated. Symmetry code used to generate equivalent atoms $0.5-x,-0.5+y,-z$.

phenol ether $\mathrm{O}$ atom (O1) forms the longest $\mathrm{Tb}-\mathrm{O}$ bond at $2.61 \AA$. The $\mathrm{Tb}-\mathrm{N}$ bonds are also quite long, with the $\mathrm{Tb}-\mathrm{N}^{\text {imine }}$ bond length at 2.536(7) $\AA$ being somewhat shorter than the Tb-N ${ }^{\text {pyridine }}$ bond 2.691(7) $\AA$. The Tb-O-Tb angles of $109.0^{\circ}$ are normal for phenolato-bridged $\mathrm{Ln}_{2}$ complexes (Fig. 3). ${ }^{10}$

The structure of the dysprosium complex $\left[\mathrm{Dy}_{2}\left(\mathrm{~L}^{2}\right)_{2}\right] \cdot 4 \mathrm{MeCN}$ (8.4MeCN) is isomorphous with 7.4MeCN (Fig. S13 $\dagger$ ), having slightly shorter Dy-O and Dy-N distances (Table 2), in agreement with the smaller ion radius of $\mathrm{Dy}^{3+} \cdot{ }^{54}$ The intramolecular Dy...Dy distance is at 3.7819(9) $\AA$. Taken together, the two ligands behave similarly in the sense that they both support phenolato-bridged $\operatorname{Ln}_{2}$ complexes, but the fashion in which this is individually achieved is strikingly different for the two cases.

\section{Magnetic properties}

The lanthanide complexes 5,7 , and 8 were further studied by variable temperature direct and alternating current ( $\mathrm{dc}$ and ac) magnetic susceptibility measurements using a SQUID-Magnetometer (MPMS Quantum Design) in order to probe their magnetic properties. All samples were desolvated at $80{ }^{\circ} \mathrm{C}$ in vacuum to remove the enclathrated solvate and intracavity MeCN molecules. The magnetic properties of compounds 1-4 have been reported previously. ${ }^{33}$

Plots of $\chi_{\mathrm{M}} T$ versus $T$ for 5, 7, and 8 are displayed in Fig. 4. At room temperature, the observed $\chi_{\mathrm{M}} T$ values are $30.79 \mathrm{~cm}^{3} \mathrm{~K}$ $\mathrm{mol}^{-1}, 25.12 \mathrm{~cm}^{3} \mathrm{~K} \mathrm{~mol}^{-1}$ and $30.49 \mathrm{~cm}^{3} \mathrm{~K} \mathrm{~mol}^{-1}$ for complexes $\mathbf{5}, \mathbf{7}$, and $\mathbf{8}$. The values for the Dy complexes $\mathbf{5}$ and $\mathbf{8}$ are slightly larger than the theoretical value of $28.34 \mathrm{~cm}^{3} \mathrm{~K} \mathrm{~mol}^{-1}$ for two non-interacting $\mathrm{Dy}^{3+}$ ions $\left({ }^{6} \mathrm{H}_{15 / 2}, S=5 / 2, L=5, g=4 / 3\right.$, $\left.\chi T=14.17 \mathrm{~cm}^{3} \mathrm{~K} \mathrm{~mol}^{-1}\right)$. In both cases, the $\chi_{\mathrm{M}} T$ values decrease slightly upon decreasing the temperature reaching $21.54 \mathrm{~cm}^{3} \mathrm{~K} \mathrm{~mol}^{-1}$ (5) and $21.17 \mathrm{~cm}^{3} \mathrm{~K} \mathrm{~mol}^{-1}$ (8) at $4 \mathrm{~K}$, respectively. This decrease is attributed to depopulation of the Stark sublevels and/or the magnetic anisotropy of the $\mathrm{Dy}^{3+}$ ions, although contributions from antiferromagnetic exchange interactions cannot be ruled out. In the $\mathrm{Gd}^{\mathrm{III}}$ complex $\mathbf{3}$, for example, a weak antiferromagnetic exchange interaction is present, $J=-0.065 \mathrm{~cm}^{-1} \cdot 33$

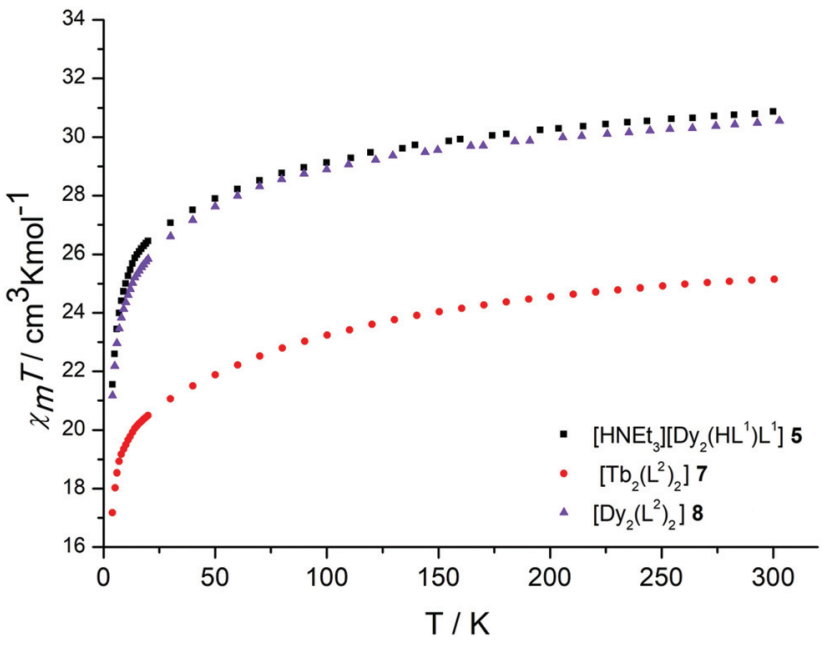

Fig. 4 Temperature dependence of the $\chi_{\mathrm{M}} T$ product (at $500 \mathrm{Oe}$ ) for the dinuclear complexes 5, 7 and $8, \chi_{\mathrm{m}}$ being the molar susceptibility per dinuclear complex defined as $\mathrm{M} / \mathrm{H}$.

The observed $\chi_{\mathrm{M}} T$ value of the $\mathrm{Tb}^{\mathrm{III}}$ complex 7 is also slightly higher than the expected value of $23.60 \mathrm{~cm}^{3} \mathrm{~K} \mathrm{~mol}^{-1}$ for two non-interacting $\mathrm{Tb}^{3+}$ ions $\left({ }^{7} \mathrm{~F}_{6}, S=3, L=3, g=3 / 2, \chi T=\right.$ $11.82 \mathrm{~cm}^{3} \mathrm{~K} \mathrm{~mol}^{-1}$ ). As observed for 5 and 8 , the $\chi_{\mathrm{M}} T$ values decrease with decreasing temperature reaching $17.17 \mathrm{~cm}^{3} \mathrm{~K}$ $\mathrm{mol}^{-1}$ at $4 \mathrm{~K}$. A similar behaviour was observed for the $\mathrm{Tb}^{\mathrm{III}}$ complex 4. $\mathrm{Tb}^{3+}$ is known to exhibit significant magnetic anisotropy, and fitting of susceptibility data is therefore difficult. $^{55}$

The field dependence of the magnetization for complexes $\mathbf{5}$, 7 and 8 was studied below $8 \mathrm{~K}$ in order to see whether magnetic anisotropy is present. Indeed, in all cases the magnetization values increase relatively rapidly at low fields and then linearly at higher field but without a clear saturation (Fig. S14$\mathrm{S} 16 \dagger)$. Thus, the magnetization values of $11.81 \mu_{\mathrm{B}}(5), 9.93 \mu_{\mathrm{B}}(7)$ or $11.92 \mu_{\mathrm{B}}$ for 8 (at $40 \mathrm{kOe}$ and $2 \mathrm{~K}$ ) are significantly lower than the theoretical value of $18 \mu_{\mathrm{B}}$ or $20 \mu_{\mathrm{B}}$ for dinuclear $\mathrm{Tb}^{\mathrm{III}}$ and Dy ${ }^{\text {III }}$ complexes. Moreover, the iso-field lines are not superposed on each other as would be expected for an isotropic system with a well-defined ground state. These observations clearly reflect the presence of significant magnetic anisotropy and/or low lying excited states. ${ }^{56,57}$

Variable temperature ac measurements were performed for $\mathbf{5}, \mathbf{7}$, and $\mathbf{8}$ in order to study their response to dynamic magnetic fields. Under a zero dc field, however, none of the complexes revealed frequency dependent in-phase $\left(\chi^{\prime}\right)$ or out-ofphase $\left(\chi^{\prime \prime}\right)$ signals, ruling out the presence of true SMM behaviour. ${ }^{4}$ This behaviour was also observed for the $\mathrm{Tb}^{\mathrm{III}}$ complex 4 and is in striking contrast to many other phenolato-bridged structures, which are true SMMs (Table 3). Inspection of the data in Table 3 shows that the known phenolato-bridged $\mathrm{Dy}_{2}$ and $\mathrm{Tb}_{2}$ SMM systems exhibit coordination numbers 8 and 9 with a more pronounced axial symmetry, a factor which is known to enhance the anisotropy. ${ }^{5}$ Our complexes (i.e. the coordination polyhedra) lack axial symmetry and magnetic an- 
Table 3 Structures and magnetic properties of selected $\mathrm{Tb}^{\prime \prime \prime}$ and Dy"I complexes exhibiting a phenolato-bridged $\mathrm{Ln}_{2} \mathrm{O}_{2}$ core structure

\begin{tabular}{|c|c|c|c|c|c|}
\hline Complex & $\mathrm{CN}$ & $\begin{array}{l}\text { Donor } \\
\text { set }\end{array}$ & Coordination geometry & $\begin{array}{l}\text { Magnetic parameters }{ }^{a} U_{\text {eff }} / \mathrm{K} \\
\left(t_{0} / \mathrm{s}\right)\end{array}$ & Ref. \\
\hline$\left[\mathrm{Tb}_{2}\left(\mathrm{HL}^{a}\right)_{4}\left(\mathrm{NO}_{3}\right)_{6}\right]$ & 9 & $\mathrm{O}_{9}$ & $\begin{array}{l}\text { Distorted spherical capped square } \\
\text { antiprism }\end{array}$ & Not determined & 20 \\
\hline$\left[\mathrm{NHEt}_{3}\right]_{2}\left[\mathrm{~Tb}_{2}-\left(\mu-\mathrm{NO}_{3}\right)_{2}\left(\mathrm{NO}_{3}\right)_{2}(\mathrm{HL})_{2}\right]^{b}$ & 9 & $\mathrm{O}_{7} \mathrm{~N}_{2}$ & Distorted muffin like & $34\left(1.1 \times 10^{-8}\right)$ & 22 \\
\hline$\left[\mathrm{NHEt}_{3}\right]_{2}\left[\mathrm{Dy}_{2}-\left(\mu-\mathrm{NO}_{3}\right)_{2}\left(\mathrm{NO}_{3}\right)_{2}(\mathrm{HL})_{2}\right]^{b}$ & 9 & $\mathrm{O}_{7} \mathrm{~N}_{2}$ & Distorted muffin-like & $80\left(2.2 \times 10^{-6}\right)$ & 22 \\
\hline$\left[\mathrm{Dy}\left(\mathrm{L}^{\circ}\right)\left(\mathrm{HL}^{\prime}\right)(\mathrm{phen})\right]$ & 8 & $\mathrm{O}_{6} \mathrm{~N}_{2}$ & Triangular dodecahedron & $160\left(9 \times 10^{-8}\right)$ & 25 \\
\hline$\left[\mathrm{Dy}_{2}(\text { bfbpen })_{2}\left(\mathrm{H}_{2} \mathrm{O}\right)_{2}\right](\mathrm{I})_{2}$ & 8 & $\mathrm{O}_{4} \mathrm{~N}_{4}$ & Square antiprism & $16.9\left(3.04 \times 10^{-6}\right)$ & 26 \\
\hline$\left[\mathrm{Dy}_{2} \mathrm{~L}_{2}\left\{\left(2-\mathrm{NO}_{2}\right) \mathrm{O}_{2} \mathrm{CPh}\right\}_{2}\right]^{d}$ & 8 & $\mathrm{O}_{5} \mathrm{~N}_{3}$ & Distorted triangular dodecahedron & $67.6\left(2.52 \times 10^{-7}\right)$ & 31 \\
\hline $\begin{array}{l}{\left[\mathrm{Dy}_{2} \mathrm{~L}_{2}\left\{(2-\mathrm{OH}) \mathrm{O}_{2} \mathrm{CPh}\right\}_{2}\right]} \\
\mathrm{MeOH} \cdot \mathrm{MeCN}^{d}\end{array}$ & 8 & $\mathrm{O}_{5} \mathrm{~N}_{3}$ & Distorted triangular dodecahedron & $51.6\left(7.50 \times 10^{-6}\right)$ & 31 \\
\hline$\left[\mathrm{Dy}_{2}(\mathrm{hmi})_{2}\left(\mathrm{NO}_{3}\right)_{2}(\mathrm{MeOH})_{2}\right]$ & 8 & $\mathrm{O}_{7} \mathrm{~N}_{1}$ & Not determined & $56\left(3 \times 10^{-7}\right)$ & 58 \\
\hline$\left[\mathrm{Dy}_{2}(\mathrm{api})_{2}\right]$ & 8 & $\mathrm{O}_{4} \mathrm{~N}_{4}$ & Square antiprism & $25.8\left(6.79 \times 10^{-6}\right)$ & 59 \\
\hline$\left[\mathrm{Dy}(\mathrm{dbm})_{2}(\mathrm{~L})\right]_{2}{ }^{e}$ & 8 & $\mathrm{O}_{6} \mathrm{~N}_{2}$ & Distorted dodecahedron & $34.5\left(1.54 \times 10^{-6}\right)$ & 60 \\
\hline$\left[\operatorname{Dy}(\mathrm{dbm})_{2}(\mathrm{~L})\right]_{2}^{f}$ & 8 & $\mathrm{O}_{6} \mathrm{~N}_{2}$ & Distorted dodecahedron & $67.6\left(6.1 \times 10^{-7}\right)$ & 9 \\
\hline
\end{tabular}

${ }^{a} \mathrm{HL}=8$-hydroxyquinaldine. ${ }^{b} \mathrm{H}_{3} \mathrm{~L}=N^{\prime}$-(2-hydroxy-3-methoxy-5-nitrobenzylidene)-2-(hydroxyamino)propanehydrazide. ${ }^{c} \mathrm{H}_{2} \mathrm{~L}=3,5$-dichloro-4hydroxy benzoic acid; phen: 1,10-phenanthroline; $\mathrm{H}_{2}$ bfbpen: $N, N^{\prime}$-bis-(2-hydroxy-5-fluoro-benzyl)- $N, N^{\prime}$-bis-(pyridin-2-ylmethyl)ethylenediamine; $\mathrm{H}_{2}$ bcbpen: $N, N^{\prime}$-bis-(2-hydroxy-5-chloro-benzyl)-N, $N^{\prime}$-bis-(pyridin-2-ylmethyl)ethylenediamine. ${ }^{d} \mathrm{H}_{2} \mathrm{~L}=N_{1}, N_{3}$-bis(4-chlorosalicyladehyde) diethylenetriamine; $\mathrm{H}_{2} \mathrm{hmi}$ : (2-hydroxy-3-methoxyphenyl)methylene (isonicotino)hydrazine; $\mathrm{H}_{3}$ api: 2-(2-hydroxyphenyl)-1,3-bis[4-(2-hydroxyphenyl)-3azabut-3-enyl]-1,3-imidazoline; dbm: 1,3-diphenyl-1,3-propanedione. ${ }^{e} \mathrm{HL}=2$-[[(4-methoxy-phenyl)imino $]$ methyl]-8-hydroxy-quinoline. ${ }^{f} \mathrm{HL}=$ 2-[[(4-ethoxyphenyl)imino]methyl]-8-hydroxyquinoline; $\mathrm{H}_{2}$ valdien: $N_{1}, N_{3}$-bis(3-methoxysalicylidene) diethylenetriamine.

a)

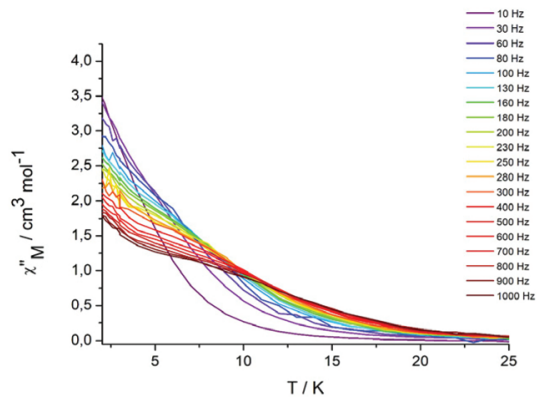

b)

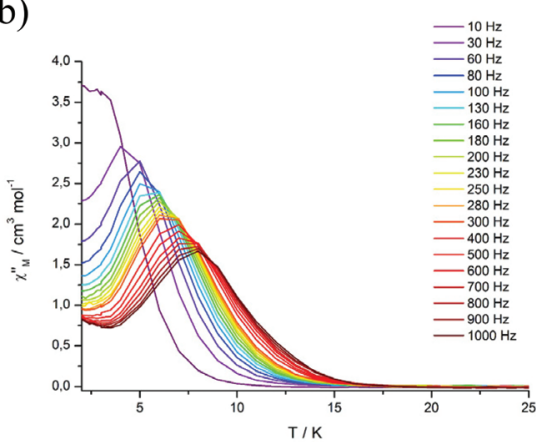

Fig. 5 Frequency dependence of the out-of-phase $\left(\chi^{\prime \prime}\right)$ ac susceptibility from 2 to $25 \mathrm{~K}$ under an applied static field (3000 Oe) at indicated frequencies for Dy ${ }_{2}$ complexes 5 (a) and 8 (b).

isotropy, and this observation is in good agreement with the reported trend. ${ }^{15}$

Variable temperature ac measurements were also performed in an applied DC field of 3 kOe to suppress quantum tunneling of the magnetization. Under these conditions, frequency dependent in-phase and out-of-phase signals could be observed, but only for the Dy complexes (Fig. 5, S17 and S18†).

Complex 5 displays only a broad shoulder between 6 and $10 \mathrm{~K}$ at $1000 \mathrm{~Hz}$. For complex 8, a well developed peak is clearly discernible with the maximum located at $8 \mathrm{~K}$ at $1000 \mathrm{~Hz}$. In both cases, an enhancement of the peak intensity is indicated as the quantum tunneling is reduced with decreasing temperature. The relaxation time $\tau$ of complex 8 derived from the $\chi^{\prime \prime}$ peaks follow the Arrhenius law (Fig. S22†) with $\tau_{0}=$
$9.01 \times 10^{-6} \mathrm{~s}$ and the effective anisotropy barrier is determined to be $\Delta E / K_{\mathrm{B}}=32.9 \mathrm{~K}$. The corresponding values for the $\mathrm{Dy}_{2}$ complex 5 are significantly smaller $\Delta E / K_{\mathrm{B}}=26.2 \mathrm{~K}$ and $\tau_{0}=$ $3.11 \times 10^{-5} \mathrm{~s}$, attributable to the changes in the coordination environments, as detailed above. The values for $\mathbf{5}$ and $\mathbf{8}$ are otherwise in a typical range seen for other $\mathrm{Dy}_{2}$ complexes displaying SMM behaviour in a dc field. ${ }^{21,26,61}$

\section{Conclusion}

In summary, a new monofunctionalized hybrid Schiff-base calix[4]arene ligand $\mathrm{H}_{3} \mathrm{~L}^{2}$, bearing a pyridyl-aldiminato podand arm has been synthesized and its ability to form dimeric com- 
plexes $\left[\operatorname{Ln}_{2}\left(\mathrm{~L}^{2}\right)_{2}\right]$ with $\mathrm{Ln}=\mathrm{Tb}^{3+}(7)$ and $\mathrm{Dy}^{3+}(8)$ has been demonstrated. The dinuclear complex $\left[\mathrm{HNEt}_{3}\right]\left[\mathrm{Dy}_{2}\left(\mathrm{HL}^{1}\right)\left(\mathrm{L}^{1}\right)\right]$ (5), where a salicylaldimine podand arm is installed at the calix[4]arene moiety, has also been successfully isolated and characterized. Crystallographic studies show that the structures supported by $\mathrm{H}_{4} \mathrm{~L}^{1}$ and $\mathrm{H}_{3} \mathrm{~L}^{2}$ differ greatly. In 7 and 8 , $\left[\operatorname{Ln}\left(\mathrm{L}^{2}\right)\right]$ monomers are linked via phenolato groups from the capping calix[4]arene, while in $\mathbf{5}$ dimerization occurs via phenolato groups from the pendant salicylaldimine units. Although both Dy compounds require applied static fields to allow for observation of their SMM, the impact of the change in the coordination environments on the dynamic magnetism is significant.

\section{Experimental section}

\section{Materials and methods}

Precursor compound 6 and the ligand $\mathrm{H}_{4} \mathrm{~L}^{1}$ were prepared as previously described. ${ }^{33}$ All other chemicals and solvents were obtained from commercial suppliers in reagent grade and were used without further purification. Melting points were determined in open-glass capillaries and are uncorrected. Mass spectra were obtained using the positive or negative electrospray ionization modus (ESI) on a Bruker Daltronics ESQUIRE 3000 Plus ITMS or Impact II UHR Qq-TOF instrument. ${ }^{1} \mathrm{H}$ and ${ }^{13} \mathrm{C}$ NMR spectra were recorded on a Bruker FOURIER 300 or a Bruker AVANCE DRX 400 spectrometer at 298 K. Chemical shifts refer to solvent signals. Mid (4000-400 $\mathrm{cm}^{-1}$ ) infrared spectra at $2 \mathrm{~cm}^{-1}$ resolution were recorded on a Bruker TENSOR 27 (equipped with a MIRacle ZnSe ATR accessory from PIKE Technologies) FT-IR spectrometer. Elemental analyses were performed on a vario EL elemental analyzer (Elementar Analysensysteme $\mathrm{GmbH}$, Hanau).

\section{Synthesis of compounds}

25-[2-((2-Methylpyridine)imino)ethoxy]-26,27,28-trihydroxycalix[4]arene $\mathbf{H}_{3} \mathbf{L}^{2}$. To a solution of calix[4]arene $6(500 \mathrm{mg}$, $1.07 \mathrm{mmol}, 1.00$ eq.) in a mixture of $\mathrm{CH}_{2} \mathrm{Cl}_{2}(75 \mathrm{~mL})$ and $\mathrm{MeOH}(75 \mathrm{~mL})$ was added pyridine-2-carbaldehyde $(111.90 \mu \mathrm{L}$, $1.18 \mathrm{mmol}, 1.10$ eq.) and an excess of $\mathrm{MgSO}_{4}$. The suspension was refluxed for $5 \mathrm{~h}$, filtered and evaporated to dryness. The remaining solid was triturated with $\mathrm{MeOH}$, filtered and washed with cold $\mathrm{MeOH}$ to give $0.44 \mathrm{~g}(74 \%)$ of pure $\mathrm{H}_{3} \mathrm{~L}^{2}$ as a white solid. Yield: $74 \%$. m.p. $209{ }^{\circ} \mathrm{C} .{ }^{1} \mathrm{H}$ NMR $(300 \mathrm{MHz}$, $\mathrm{CD}_{2} \mathrm{Cl}_{2}$, see Fig. $\mathrm{S} 1 \dagger$ for labeling scheme): $\delta 3.36-3.39(\mathrm{~d}, 2 \mathrm{H}$, $\left.{ }^{2} J=13.7 \mathrm{~Hz}, \mathrm{Ar}-\mathrm{CH}_{\mathrm{eq}} \mathrm{H}-\mathrm{Ar}, \mathrm{C}^{8 / 14}\right) ; 3.45-3.48\left(\mathrm{~d}, 2 \mathrm{H},{ }^{2} J=13.0\right.$ $\left.\mathrm{Hz}, \mathrm{Ar}-\mathrm{CH}_{\mathrm{eq}} \mathrm{H}-\mathrm{Ar}, \mathrm{C}^{2 / 20}\right)$; 4.06-4.10 (d, $2 \mathrm{H},{ }^{2} J=13.7 \mathrm{~Hz}, \mathrm{Ar}-$ $\left.\mathrm{CH}_{\mathrm{ax}} \mathrm{H}-\mathrm{Ar}, \mathrm{C}^{8 / 14}\right) ; 4.36-4.49\left(\mathrm{~m}, 6 \mathrm{H}, \mathrm{O}-\mathrm{CH}_{2}, \mathrm{CH}_{2}-\mathrm{N}, \mathrm{Ar}-\right.$ $\left.\mathrm{CH}_{\mathrm{ax}} \mathrm{H}-\mathrm{Ar}, \mathrm{C}^{29}, \mathrm{C}^{30}, \mathrm{C}^{2 / 20}\right)$; 6.61-6.66 (m, 3 H, para $\mathrm{ArH}, \mathrm{C}^{11}$, $\left.\mathrm{C}^{5 / 17}\right)$; 6.88-6.90 (t, $1 \mathrm{H},{ }^{3} \mathrm{~J}=7.6 \mathrm{~Hz}$, para $\left.\mathrm{ArH}, \mathrm{C}^{23}\right)$; 6.95-6.99 $\left(\mathrm{m}, 4 \mathrm{H}\right.$, meta $\left.\mathrm{ArH}, \mathrm{C}^{10 / 12}, \mathrm{C}^{6 / 16}\right) ; 7.04-7.10(\mathrm{~m}, 4 \mathrm{H}$, meta $\mathrm{ArH}$, $\left.\mathrm{C}^{4 / 18}, \mathrm{C}^{22 / 24}\right)$; 7.31-7.34 (m, $\left.1 \mathrm{H}, \mathrm{H}_{\mathrm{py}}, \mathrm{C}^{35}\right) ; 7.69-7.73(\mathrm{~m}, 1 \mathrm{H}$, $\left.\mathrm{H}_{\mathrm{py}}, \mathrm{C}^{34}\right) ; 8.18-8.20\left(\mathrm{~d}, 1 \mathrm{H},{ }^{2} J=7.9 \mathrm{~Hz}, \mathrm{H}_{\mathrm{py}}, \mathrm{C}^{33}\right) ; 8.68-8.69(\mathrm{~d}$, $\left.1 \mathrm{H},{ }^{2} J=4.5 \mathrm{~Hz}, \mathrm{H}_{\mathrm{py}}, \mathrm{C}^{36}\right) ; 8.77\left(\mathrm{~s}, 1 \mathrm{H}, \mathrm{N}=\mathrm{CH}, \mathrm{C}^{31}\right) .{ }^{13} \mathrm{C}\left\{{ }^{1} \mathrm{H}\right\}$
NMR (100 MHz, $\mathrm{CD}_{2} \mathrm{Cl}_{2}$, see Fig. S1 $\uparrow$ for labeling scheme): $\delta$ $31.85\left(\mathrm{Ar}-\mathrm{CH}_{2}-\mathrm{Ar}, \mathrm{C}^{2 / 20}\right) ; 32.11\left(\mathrm{Ar}-\mathrm{CH}_{2}-\mathrm{Ar}, \mathrm{C}^{8 / 14}\right) ; 61.13\left(\mathrm{CH}_{2}-\right.$ $\left.\mathrm{N}, \mathrm{C}^{30}\right) ; 76.54\left(\mathrm{O}-\mathrm{CH}_{2}, \mathrm{C}^{29}\right) ; 121.06\left(\right.$ para $\left.\mathrm{C}^{\mathrm{Ar}}, \mathrm{C}^{5 / 17}\right) ; 121.76$ $\left(\mathrm{C}^{\mathrm{py}}, \mathrm{C}^{33}\right) ; 122.08\left(\right.$ para $\left.\mathrm{C}^{\mathrm{Ar}}, \mathrm{C}^{11}\right) ; 125.44\left(\mathrm{C}^{\mathrm{py}}, \mathrm{C}^{35}\right) ; 126.33$ (para $\mathrm{C}^{\mathrm{Ar}}, \mathrm{C}^{23}$ ); 128.74 (ortho $\mathrm{C}^{\mathrm{Ar}}, \mathrm{C}^{7 / 15}$ ); 128.83 (ortho $\mathrm{C}^{\mathrm{Ar}}, \mathrm{C}^{3 / 19}$ ); $128.99\left(\right.$ meta $\left.\mathrm{C}^{\mathrm{Ar}}, \mathrm{C}^{4 / 18}\right) ; 129.12\left(\right.$ meta $\left.\mathrm{C}^{\mathrm{Ar}}, \mathrm{C}^{6 / 16}\right) ; 129.20$ (ortho $\left.\mathrm{C}^{\mathrm{Ar}}, \mathrm{C}^{9 / 13}\right) ; 129.25\left(\right.$ meta $\left.\mathrm{C}^{\mathrm{Ar}}, \mathrm{C}^{10 / 12}\right) ; 129.85\left(\right.$ meta $\left.\mathrm{C}^{\mathrm{Ar}}, \mathrm{C}^{22 / 24}\right)$; 134.87 (ortho $\left.\mathrm{C}^{\mathrm{Ar}}, \mathrm{C}^{1 / 21}\right) ; 137.00\left(\mathrm{C}^{\mathrm{py}}, \mathrm{C}^{34}\right) ; 149.87\left(\mathrm{C}^{\mathrm{Ar}}-\mathrm{OH}\right.$, $\left.\mathrm{C}^{27}\right) ; 149.91\left(\mathrm{C}^{\mathrm{py}}, \mathrm{C}^{36}\right) ; 151.66\left(\mathrm{C}^{\mathrm{Ar}}-\mathrm{OH}, \mathrm{C}^{26 / 28}\right) ; 152.23\left(\mathrm{C}^{\mathrm{Ar}}-\mathrm{OH}\right.$, $\left.\mathrm{C}^{25}\right) ; 155.28\left(\mathrm{C}^{\mathrm{py}}, \mathrm{C}^{32}\right) ; 165.86\left(\mathrm{C}=\mathrm{N}, \mathrm{C}^{31}\right)$. ATR-IR $(\mathrm{ZnSe})$ $\nu / \mathrm{cm}^{-1}=3285(\mathrm{~s}), 2927(\mathrm{~m}), 1651(\mathrm{~m}), 1592(\mathrm{~m}), 1465(\mathrm{~s}), 1439$ (s), 1375 (m), 1246 (s), 1193 (s), 1084 (w), 1044 (m), 921 (w), $822(\mathrm{w}), 786$ (w), 768 (w), 751 (s). $\mathrm{m} / \mathrm{z}$ (ESI+, MeCN): $\mathrm{C}_{36} \mathrm{H}_{32} \mathrm{~N}_{2} \mathrm{O}_{4}$ (556.24) $\left[\mathrm{M}+\mathrm{H}^{+}\right]^{+}$calcd: 557.24; found 557.2; [M + $\left.\mathrm{Na}^{+}\right]^{+}$calcd: 579.23; found: 579.2. Elemental analysis for $\mathrm{C}_{36} \mathrm{H}_{32} \mathrm{~N}_{2} \mathrm{O}_{4} \cdot \mathrm{H}_{2} \mathrm{O}(556.66+18.02)$ calc. C $75.24, \mathrm{~N} 4.87, \mathrm{H}$ $5.96 \%$; found. C $75.11, \mathrm{~N} 4.85$, H 5.62\%.

$\left[\mathrm{HNEt}_{3}\right]\left[\mathrm{Dy}_{2}\left(\mathbf{H L}^{1}\right)\left(\mathbf{L}^{1}\right)\right](5)$. To a solution of $\mathrm{H}_{4} \mathrm{~L}^{1}$ (100 mg, $0.175 \mathrm{mmol}, 1.00$ eq.) in $\mathrm{CH}_{2} \mathrm{Cl}_{2}(5 \mathrm{~mL})$ was added a solution of $\mathrm{Dy}\left(\mathrm{NO}_{3}\right)_{3} \cdot 6 \mathrm{H}_{2} \mathrm{O}(88 \mathrm{mg}, 0.192 \mathrm{mmol}, 1.1$ eq.) in $\mathrm{MeOH}$ $(5 \mathrm{~mL})$ followed by triethylamine $(0.110 \mathrm{ml}, 0.787 \mathrm{mmol}, 4.5$ eq.). The resulting mixture was stirred for $12 \mathrm{~h}$, the $\mathrm{CH}_{2} \mathrm{Cl}_{2}$ was evaporated under vacuum to give a solid, which was filtered and washed with cold $\mathrm{MeOH}$ to give the title compound as a yellow powder. Yield: $79 \%$. m.p. $243{ }^{\circ} \mathrm{C}$. ATR-IR (ZnSe) $\nu / \mathrm{cm}^{-1}$ 3439 (m), 3059 (w), 2912 (m), 1635 (s), 1591 (m), 1544 (m), 1461 (s), 1327 (s), 1301 (s), 1192 (m), 1155 (m), 1083 (m), 903 (m), $870(\mathrm{w}), 757$ (s), $515(\mathrm{w}) . \mathrm{C}_{80} \mathrm{H}_{75} \mathrm{~N}_{3} \mathrm{O}_{10} \mathrm{Dy}_{2}$ (1555.396) [2M $\left.-\mathrm{HNEt}_{3}{ }^{+}\right]^{-}$calcd: 1461.29; found 1461.25; [M] $]^{-}$calcd 730.14; found 730.12. Elemental analysis for $\mathrm{C}_{80} \mathrm{H}_{75} \mathrm{Dy}_{2} \mathrm{~N}_{3} \mathrm{O}_{10} \cdot 5 \mathrm{H}_{2} \mathrm{O}$ $(1563.49+90.08)$ calc. C 58.11, N 2.54, H 5.18\%; found. C $57.93, \mathrm{~N} 2.42, \mathrm{H} 5.31 \%$.

$\left[\mathrm{Tb}_{2}\left(\mathbf{L}^{2}\right)_{2}\right](7)$. To a solution of $\mathrm{H}_{3} \mathrm{~L}^{2}(100 \mathrm{mg}, 0.180 \mathrm{mmol}$, 1.00 eq.) in $\mathrm{CH}_{2} \mathrm{Cl}_{2}(5 \mathrm{~mL})$ was added a solution of $\mathrm{Tb}$ $\left(\mathrm{NO}_{3}\right)_{3} \cdot 6 \mathrm{H}_{2} \mathrm{O}(90 \mathrm{mg}, 0.198 \mathrm{mmol}, 1.1$ eq.) in $\mathrm{MeOH}(5 \mathrm{~mL})$ followed by triethylamine $(0.087 \mathrm{ml}, 0.629 \mathrm{mmol}, 3.5 \mathrm{eq}$.$) . The$ resulting mixture was stirred for $12 \mathrm{~h}$, the $\mathrm{CH}_{2} \mathrm{Cl}_{2}$ was evaporated under vacuum to give a solid, which was filtered and washed with cold $\mathrm{MeOH}$ to give the title compound 7 as a yellow powder. Yield: 85\%. m.p. $233{ }^{\circ} \mathrm{C}$ (decomp.). ATR-IR (ZnSe) $\nu / \mathrm{cm}^{-1}=3049(\mathrm{w}), 2911(\mathrm{w}), 1652(\mathrm{w}), 1584(\mathrm{~m}), 1457$ (s), 1419 (m), 1329 (m), 1307 (m), 1244 (m), 1186 (m), 1082 (m), $1043(\mathrm{w}), 933(\mathrm{w}), 870(\mathrm{w}), 830(\mathrm{w}), 760(\mathrm{~s}), 516(\mathrm{w}) . \mathrm{m} / \mathrm{z}$ (ESI+, $\left.\mathrm{CH}_{2} \mathrm{Cl}_{2} / \mathrm{MeCN}\right): \mathrm{C}_{72} \mathrm{H}_{58} \mathrm{~N}_{4} \mathrm{O}_{8} \mathrm{~Tb}_{2}$ (1425.13) $\left[2 \mathrm{M}+\mathrm{Na}^{+}\right]^{+}$ calcd: 1447.27 ; found 1447.29, $\left[2 \mathrm{M}+\mathrm{K}^{+}\right]^{+}$calcd: 1463.24; found: 1463.27, $\left[\mathrm{M}+\mathrm{H}^{+}\right]^{+}$calcd: 713.14; found 713.16 Elemental analysis for $\mathrm{C}_{72} \mathrm{H}_{58} \mathrm{~N}_{4} \mathrm{O}_{8} \mathrm{~Tb}_{2} \cdot \mathrm{H}_{2} \mathrm{O}(1425.13+18.02)$ calc. C 59.92; N 3.88; H 4.19\%; found C 59.83; N 3.70; H $4.07 \%$.

[Dy $\left.\mathbf{D}_{2}\left(\mathbf{L}^{2}\right)_{2}\right](8)$. To a solution of $\mathrm{H}_{3} \mathrm{~L}^{2}(100 \mathrm{mg}, 0.180 \mathrm{mmol}$, 1.00 eq.) in $\mathrm{CH}_{2} \mathrm{Cl}_{2}(5 \mathrm{~mL})$ was added a solution of Dy $\left(\mathrm{NO}_{3}\right)_{3} \cdot 6 \mathrm{H}_{2} \mathrm{O}(90 \mathrm{mg}, 0.198 \mathrm{mmol}, 1.1$ eq.) in $\mathrm{MeOH}(5 \mathrm{~mL})$ followed by triethylamine $(0.087 \mathrm{ml}, 0.629 \mathrm{mmol}, 3.5$ eq. $)$. The resulting mixture was stirred for $12 \mathrm{~h}$, the $\mathrm{CH}_{2} \mathrm{Cl}_{2}$ was evaporated under vacuum to give a solid, which was filtered and washed with cold $\mathrm{MeOH}$ to give complex $\mathbf{8}$ as a green-yellow 
powder. Yield: 87\%. m.p. $236{ }^{\circ} \mathrm{C}$ (decomp.). ATR-IR (ZnSe) $\nu / \mathrm{cm}^{-1}=3055(\mathrm{w}), 2915(\mathrm{w}), 1655(\mathrm{~m}), 1588(\mathrm{~m}), 1458(\mathrm{~s}), 1423$ (m), 1327 (m), 1306 (m), 1245 (w), 1189 (m), 1084 (m), 1042 (w), $913(\mathrm{w}), 868(\mathrm{w}), 830(\mathrm{w}), 756(\mathrm{~s}), 516(\mathrm{w}) . \mathrm{m} / \mathrm{z}$ (ESI+, $\left.\mathrm{CH}_{2} \mathrm{Cl}_{2} / \mathrm{MeCN}\right): \mathrm{C}_{72} \mathrm{H}_{58} \mathrm{~N}_{4} \mathrm{O}_{8} \mathrm{Dy}_{2}$ (1432.28) $\left[2 \mathrm{M}+\mathrm{H}^{+}\right]^{+}$calcd: 1433.28; found 1433.22, $\left[2 \mathrm{M}+\mathrm{Na}^{+}\right]^{+}$calcd: 1455.27; found 1455.20, $\left[\mathrm{M}+\mathrm{H}^{+}\right]^{+}$calcd: 717.14; found 717.1, $\left[\mathrm{M}+\mathrm{Na}^{+}\right]^{+}$ calcd: 740.13; found 740.1. Elemental analysis for $\mathrm{C}_{72} \mathrm{H}_{58} \mathrm{~N}_{4} \mathrm{O}_{8} \mathrm{Dy}_{2} \cdot \mathrm{H}_{2} \mathrm{O}(1432.28+18.02)$ calc. C 59.63; N 3.86; H 4.17\%; found C 59.72; N 3.96; H 3.99\%.

\section{X-ray crystallography}

Single crystals of $\left[\mathrm{Tb}_{2}\left(\mathrm{~L}^{2}\right)_{2}\right] \cdot 4 \mathrm{MeCN} \quad(7 \cdot 4 \mathrm{MeCN})$ and $\left[\mathrm{Dy}_{2}\left(\mathrm{~L}^{2}\right)_{2}\right] \cdot 4 \mathrm{MeCN}(\mathbf{8} \cdot 4 \mathrm{MeCN})$ were obtained from acetonitrile. Suitable specimens were selected and mounted on the tip of a glass needle using perfluoropolyether oil. The data sets were collected at 180(2) K using a STOE Stadivari diffractometer equipped with graphite monochromated $\mathrm{Cu}-\mathrm{K}_{\alpha}$ radiation $(\lambda=$ $1.54186 \AA$ A). The data were processed with the program XAREA. $^{62}$ The structure was solved by direct methods ${ }^{63}$ and refined by full-matrix least-squares techniques on the basis of all data against $F^{2}$ using SHELXL-2014/7.64 PLATON was used to search for higher symmetry. ${ }^{45}$ Two of the four MeCN solvate molecules in the structures of $7 \cdot 4 \mathrm{MeCN}$ and $8.4 \mathrm{MeCN}$ were found to be heavily disordered and all attempts to model this disorder failed. The corresponding electron density was removed from the structures (and the corresponding $F_{0}$ ) with the Squeeze algorithm implemented in the Platon program suite. The SQUEEZE routine revealed total potential solvent area of $150 \AA^{3}$ per unit cell for $7 \cdot 4 \mathrm{MeCN}$ and $8 \cdot 4 \mathrm{MeCN}$ corresponding to approximately two MeCN solvate molecules per formula unit. All non-hydrogen atoms were refined anisotropically. Graphics were produced with Ortep3 for Windows and PovRAY.

Crystal data for $\left[\mathrm{Tb}_{2}\left(\mathrm{~L}^{2}\right)_{2}\right] \cdot 4 \mathrm{MeCN} \quad(7 \cdot 4 \mathrm{MeCN})$. $\mathrm{C}_{72} \mathrm{H}_{58} \mathrm{~N}_{4} \mathrm{O}_{8} \mathrm{~Tb}_{2} \cdot 4 \mathrm{MeCN}, M=1589.31 \mathrm{~g} \mathrm{~mol}^{-1}$, orthorhombic space group Pccn, $a=16.8317(4), b=17.0263(5), c=22.5381(6)$ $\AA, V=6459.0(3) \AA^{3}, Z=4$ (the asymmetric units contains one half of the formula unit), $\rho_{\text {calc }}=1.55 \mathrm{~g} \mathrm{~cm}^{-3}, \mu=11.132 \mathrm{~mm}^{-1}$, 69266 reflections collected, 6114 unique. Final $R_{1}\left[F^{2}>2 \sigma\left(F^{2}\right)\right]$ $=0.0719, \mathrm{w} R_{2}$ (all data) $=0.1835$.

Crystal data for $\left[\mathrm{Dy}_{2}\left(\mathrm{~L}^{2}\right)_{2}\right] \cdot 4 \mathrm{MeCN} \quad(8 \cdot 4 \mathrm{MeCN})$. $\mathrm{C}_{72} \mathrm{H}_{58} \mathrm{Dy}_{2} \mathrm{~N}_{4} \mathrm{O}_{8} \cdot 4 \mathrm{MeCN}, M=1596.39 \mathrm{~g} \mathrm{~mol}^{-1}$, orthorhombic space group Pccn, $a=16.8208(5), b=16.9909(4), c=22.5406(7)$ $\AA, V=6442.1(3) \AA^{3}, Z=4$ (the asymmetric units contains one half of the formula unit), $\rho_{\text {calc }}=1.561 \mathrm{~g} \mathrm{~cm} \mathrm{~cm}^{-3}, \mu=$ $12.775 \mathrm{~mm}^{-1}, 69509$ reflections collected, 6070 unique. Final $R_{1}\left[F^{2}>2 \sigma\left(F^{2}\right)\right]=0.0713, \mathrm{w} R_{2}$ (all data) $=0.2067$.

CCDC 2011007 (7) and $2011008(8) \dagger$ contain the supplementary crystallographic data for this paper.

\section{SQUID magnetometry}

Magnetic susceptibility measurements were carried out on a MPMS Quantum Design SQUID-magnetometer in the temperature range of 2-300 K. DC measurements were performed from $2-300 \mathrm{~K}$ in an applied external field of $0.5 \mathrm{~T}$. AC measurements were collected in a 3.0 Oe ac field at various frequencies (10-1000 Hz) with an applied 3 kOe dc field.

\section{Conflicts of interest}

There are no conflicts of interest to declare.

\section{Acknowledgements}

We are thankful to Prof. Dr H. Krautscheid for providing facilities for X-ray crystallographic measurements. Financial support from the German Federal Ministry of Education and Research (BMBF - project 02NUK046C, "FENABIUM") is gratefully acknowledged. YP and AKP gratefully acknowledge funding from the DFG SFB/TRR88 "3Met”.

\section{References}

1 D. Gatteschi, R. Sessoli and J. Villain, Molecular Nanomagnets, Oxford University Press, Oxford, 2006.

2 S. Hill, R. S. Edwards, N. Aliaga-Alcalde and G. Christou, Science, 2003, 302, 1015-1018.

3 M. N. Leuenberger and D. Loss, Nature, 2001, 410, 789-793.

4 D. N. Woodruff, R. E. P. Winpenny and R. A. Layfield, Chem. Rev., 2013, 113, 5110-5148.

5 J. D. Rinehart and J. R. Long, Chem. Sci., 2011, 2, 20782085.

6 L. Sorace, C. Benelli and D. Gatteschi, Chem. Soc. Rev., 2011, 40, 3092-3104.

7 R. Sessoli and A. K. Powell, Coord. Chem. Rev., 2009, 253, 2328-2341.

8 N. Ishikawa, M. Sugita, T. Ishikawa, S. Koshihara and Y. Kaizu, J. Am. Chem. Soc., 2003, 125, 8694-8695.

9 J. Long, F. Habib, P.-H. Lin, I. Korobkov, G. Enright, L. Ungur, W. Wernsdorfer, L. F. Chibotaru and M. Murugesu, J. Am. Chem. Soc., 2011, 133, 5319-5328.

10 P.-H. Lin, W.-B. Sun, M.-F. Yu, G.-M. Li, P.-F. Yan and M. Murugesu, Chem. Commun., 2011, 47, 10993-10995.

11 S. Takamatsu, T. Ishikawa, S.-Y. Koshihara and N. Ishikawa, Inorg. Chem., 2007, 46, 7250-7252.

12 S.-D. Jiang, B.-W. Wang, G. Su, Z.-M. Wang and S. Gao, Angew. Chem., Int. Ed., 2010, 49, 7448-7451.

13 F. Gao, L. Cui, Y. Song, Y.-Z. Li and J.-L. Zuo, Inorg. Chem., 2014, 53, 562-567.

14 F. Luan, T. Liu, P. Yan, X. Zou, Y. Li and G. Li, Inorg. Chem., 2015, 54, 3485-3490.

15 M. Ren, Z.-L. Xu, S.-S. Bao, T.-T. Wang, Z.-H. Zheng, R. A. S. Ferreira, L.-M. Zheng and L. D. Carlos, Dalton Trans., 2016, 45, 2974-2982.

16 K. R. Vignesh, D. I. Alexandropoulos, B. S. Dolinar and K. R. Dunbar, Dalton Trans., 2019, 48, 2872-2876.

17 R. Barhoumi, A. Amokrane, S. Klyatskaya, M. Boero, M. Ruben and J.-P. Bucher, Nanoscale, 2019, 11, 2116721179. 
18 M. Studniarek, C. Wäckerlin, A. Singha, R. Baltic, K. Diller, F. Donati, S. Rusponi, H. Brune, Y. Lan, S. Klyatskaya, M. Ruben, A. P. Seitsonen and J. Dreiser, Adv. Sci., 2019, 6, 1901736.

19 R. J. Holmberg, M. A. Polovkova, A. G. Martynov, Y. G. Gorbunova and M. Murugesu, Dalton Trans., 2016, 45, 9320-9327.

20 L. Mandal, S. Biswas, G. Cosquer, Y. Shen and M. Yamashita, Dalton Trans., 2018, 47, 17493-17499.

21 T. Morita, M. Damjanovic, K. Katoh, Y. Kitagawa, N. Yasuda, Y. Lan, W. Wernsdorfer, B. K. Breedlove, M. Enders and M. Yamashita, J. Am. Chem. Soc., 2018, 140, 2995-3007.

22 P. Kalita, J. Goura, J. M. H. Martinez, E. Colacio and V. Chandrasekhar, Eur. J. Inorg. Chem., 2019, 212-220.

23 G. Velkos, D. S. Krylov, K. Kirkpatrick, L. Spree, V. Dubrovin, B. Büchner, S. M. Avdoshenko, V. Bezmelnitsyn, S. Davis, P. Faust, J. Duchamp, H. C. Dorn and A. A. Popov, Angew. Chem., Int. Ed., 2019, 58, 5891-5896.

24 K. Katoh, B. K. Breedlove and M. Yamashita, Chem. Sci., 2016, 7, 4329-4340.

25 J.-W. Zhang, Y. Man, W.-H. Liu, B.-Q. Liu and Y.-P. Dong, Dalton Trans., 2019, 48, 2560-2563.

26 X. Ma, B. Chen, Y.-Q. Zhang, J. Yang, Q. Shi, Y. Ma and X. Liu, Dalton Trans., 2019, 48, 12622-12631.

27 S. Biswas, L. Mandal, Y. Shen and M. Yamashita, Dalton Trans., 2019, 48, 14096-14102.

28 M. Li, H. Wu, Z. Xia, V. Montigaud, O. Cador, B. Le Guennic, H. Ke, W. Wang, G. Xie and S. Chen, Chem. Commun., 2019, 55, 14661-14664.

29 G. Huang, X. Yi, F. Gendron, B. Le Guennic, T. Guizouarn, C. Daiguebonne, G. Calvez, Y. Suffren, O. Guillou and K. Bernot, Dalton Trans., 2019, 48, 16053-16061.

30 Y.-X. Zhang, X.-Y. Cheng, Y.-T. Tang, Y.-H. Zhang, S.-C. Wang, H.-Y. Wei and Z.-L. Wu, Polyhedron, 2019, 166, 23-27.

31 Y. Ge, D. Li, G. Wang, Y. Cui, M. S. Najib, Y. Li and B.-L. Wang, Chem. - Asian J., 2019, 14, 2846-2852.

32 P. Liu, C. Li and W.-J. Yuan, Inorg. Chim. Acta, 2019, 490, 1-5.

33 S. Ullmann, P. Hahn, L. Blömer, A. Mehnert, C. Laube, B. Abel and B. Kersting, Dalton Trans., 2019, 48, 3893-3905.

34 M. Massi and M. I. Ogden, Materials, 2017, 10, 1369-1381.

35 R. K. Pathak, A. G. Dikundwar, T. N. Guru Row and C. P. Rao, Chem. Commun., 2010, 46, 4345-4347.

36 D. D’Alessio, S. Muzzioli, B. W. Skelton, S. Stagni, M. Massi and M. I. Ogden, Dalton Trans., 2012, 41, 4736-4739.

37 R. K. Pathak, V. K. Hinge, M. Mondal and C. P. Rao, J. Org. Chem., 2011, 76, 10039-10049.

38 R. Joseph, J. P. Chinta and C. P. Rao, Inorg. Chem., 2011, 50, 7050-7058.

39 V. V. S. Mummidivarapu, V. K. Hinge and C. P. Rao, Dalton Trans., 2015, 44, 1130-1141.

40 R. K. Pathak, V. K. Hinge, A. Rai, D. Panda and C. P. Rao, Inorg. Chem., 2012, 51, 4994-5005.

41 S. Ullmann, R. Schnorr, M. Handke, C. Laube, B. Abel, J. Matysik, M. Findeisen, R. Rüger, T. Heine and B. Kersting, Chem. - Eur. J., 2017, 23, 3824-3827.
42 S. Ullmann, R. Schnorr, C. Laube, B. Abel and B. Kersting, Dalton Trans., 2018, 47, 5801-5811.

43 S. Bhagat and A. K. Chakraborti, J. Org. Chem., 2007, 72, 1263-1270.

44 K. Nakamoto, Infrared and Raman Spectra of Inorganic and Coordination Compounds, Part B, John Wiley \& Sons, Inc., Hoboken, New Jersey, 6th edn, 2009.

45 A. L. Spek, PLATON - A Multipurpose Crystallographic Tool, Utrecht University, Utrecht, The Netherlands, 2000.

46 W. E. I. Xu, R. J. Puddephatt and C. S. Frampton, J. Inclusion Phenom. Mol. Recognit. Chem., 1994, 19, 277290.

47 M. Llunell, D. Casanova, J. Cirera, P. Alemany and S. Alvarez, SHAPE version 2.1, University of Barcelona, Barcelona, 2013.

48 B. M. Furphy, J. M. Harrowfield, M. I. Ogden, B. W. Skelton, A. H. White and F. R. Wilner, J. Chem. Soc., Dalton Trans., 1989, 478, 2217-2221.

49 G. B. Deacon, M. G. Gardiner, P. C. Junk, J. P. Townley and J. Wang, Organometallics, 2012, 31, 3857-3864.

50 L. Zou, L. Zhao, P. Chen, Y.-N. Guo, Y. Guo, Y.-H. Li and J. Tang, Dalton Trans., 2012, 41, 2966-2971.

51 Y.-N. Guo, G.-F. Xu, W. Wernsdorfer, L. Ungur, Y. Guo, J. Tang, H.-J. Zhang, L. F. Chibotaru and A. K. Powell, J. Am. Chem. Soc., 2011, 133, 11948-11951.

52 Y.-N. Guo; X.-H. Chen, S. Xue and J. Tang, Inorg. Chem., 2011, 50, 9705-9713.

53 G. L. Nealon, M. Mocerino, M. I. Ogden and B. W. Skelton, J. Inclusion Phenom. Macrocyclic Chem., 2009, 65, 25-30.

54 R. D. Shannon, Acta Crystallogr., Sect. A: Cryst. Phys., Diffr., Theor. Gen. Crystallogr., 1976, 32, 751-767.

55 P.-H. Lin, M. Leclère, J. Long, T. J. Burchell, I. Korobkov, R. Clérac and M. Murugesu, Dalton Trans., 2010, 39, 56985704.

56 L. Zhang, S. Lu, C. Zhang, C. Du and H. Hou, CrystEngComm, 2015, 846-855.

57 S. Osa, T. Kido, N. Matsumoto, N. Re, A. Pochaba and J. Mrozinski, J. Am. Chem. Soc., 2004, 126, 420-421.

58 P.-H. Lin, T. J. Burchell, R. Clerac and M. Murugesu, Angew. Chem., Int. Ed., 2008, 47, 8848-8851.

59 M. Nematirad, W. J. Gee, S. K. Langley, N. F. Chilton, B. Moubaraki, K. S. Murray and S. R. Batten, Dalton Trans., 2012, 41, 13711-13715.

60 W.-M. Wang, W.-Z. Qiao, H.-X. Zhang, S.-Y. Wang, Y.-Y. Nie, H.-M. Chen, Z. Lui, H.-L. Gao, J.-Z. Cui and B. Zhao, Dalton Trans., 2016, 45, 8182-8191.

61 W. R. Reed, M. A. Dunstan, R. W. Gable, W. Phonsri, K. S. Murray, R. A. Mole and C. Boskovic, Dalton Trans., 2019, 48, 15635-15645.

62 Stoe \& Cie, $X$-AREA and $X$-RED 32, V1.35, Stoe \& Cie, Darmstadt, Germany, 2006.

63 G. M. Sheldrick, Acta Crystallogr., Sect. A: Found. Crystallogr., 1990, 46, 467-473.

64 G. M. Sheldrick, SHELXL-97, Computer program for crystal structure refinement, University of Göttingen, Göttingen, Germany, 1997. 